\title{
IJBF INSTITUTIONAL AND MACROECONOMIC DETERMINANTS OF STOCK MARKET DEVELOPMENT IN MENA REGION: NEW RESULTS FROM A PANEL DATA ANALYSIS
}

\author{
Mondher Cherif and Kaouthar Gazdar \\ Rheims University Euromed Marscille CEMM \\ and Rheims University
}

\begin{abstract}
This paper provides new evidence on the influence of macroeconomic environment and institutional quality on stock market development, using data from 14 MENA countries over the period of 1990-2007. Using both panel data and instrumental variable techniques, we found that income level, saving rate, stock market liquidity, and interest rate influence stock market development with the expected theoretical signs. Our results also showed that the banking and the stock market sectors are complementary instead of being substitutes. We found that the institutional environment as captured by a composite policy risk index does not appear to be a driving force for the stock market capitalisation in the region. Our last results are robust to different specifications and empirical techniques.
\end{abstract}

Keywords: Ethnic heterogeneity, Institutions, Instrumental variable technique, MENA countries, Political risk, Panel data.

JEL Classifications: G20, G28, O55.

\section{Introduction}

As an integral part of financial development, stock markets have received over the last decade, a great deal of attention as a source of economic growth. The theoretical argument for linking financial development to growth is that a well-developed financial system performs several critical functions to enhance the efficiency of intermediation by reducing information, transaction, and monitoring costs. Indeed, several previous studies on finance and development highlight that countries with better developed financial systems would experience faster economic growth. Then, the question of what determines stock market development becomes important and is the subject of a large and still growing research literature from which some general conclusions can be drawn. In brief, 
there is agreement that countries should adopt appropriate macroeconomic policies, encourage competition within the financial sector, and develop a strong and transparent institutional and legal framework for financial sector activities.

The development of equity markets is crucial toward further development of the financial system. The stock market increases flexibility in the financial intermediation process, as it provides investors with a clear exit strategy. Further more, the stock market provides an important indicator for information sharing among investors, company valuation, and the prospect of macroeconomic fundamentals.

Indeed, banks dominate financing in several developing and even in most developed countries, and stock markets remain a small part of the overall financial system. Early research emphasized the role of the banking sector in economic growth. King and Levine (1993a, b) show that bank development affects economic growth in a sample of more than 80 countries. Levine (1997) (Levine Zervos, 1998), Beck, Demirguc and Levine (2000) and Levine, Loayza and Beck (2000) have confirmed this finding. However, these studies have omitted the role of the stock market and recent research has therefore begun to focus on the linkages between the stock markets and economic development. With the growing importance of stock markets in the context of financial liberalization and global integration, a number of theoretical and empirical studies have focused on stock market indicators and economic growth. Their findings showed how stock market development might boost economic growth. Levine and Zervos (1998), for instance, found that stock market development plays an important role in predicting future economic growth. The results of Beck and Levine (2004) confirmed these findings. Using a panel data set of 40 countries and applying the generalized method of moment technique, they found that stock markets and banks positively influence economic growth.

While the question of whether stock markets promote economic growth has gained considerable attention in academic and policy works, there are little theoretical and empirical studies on the determinants of stock market development in MENA countries. MENA countries have embarked on economic reform and structural adjustment programs. However, they have not yet emerged as economics powers, which May explain the lack of research on MENA capital markets (Ben Naceur, 4 (2007)). From a geographical perspective, relatively little of the recent research in financial development has been directed at the MENA region. Hence, the purpose of this paper is to fill the void in the literature and make an in-depth analysis of the MENA financial sector in order to identify their main determinants.

To better understand what drives the stock market development in this region, we explored in this paper both macroeconomic and potential institutional determinants. The scope of our study covered 14 MENA countries during the 19902007 periods. We employed two different econometric methodologies. Firstly, we use a panel data analysis under the fixed and random effects specifications. Our results show that while macroeconomic factors such as saving rate, financial intermediary development, and stock market liquidity are important determinants of stock market development in the MENA region, institutional environment is 
not a good predictor of stock market capitalization. Thus, the political risk index has no significant effect on stock market development. Secondly, building on the institution and development literature, we applied the instrumental variable (IV) techniques that besides endogeneity ${ }^{1}$ accounts for measurement error in the institutional quality proxies. In doing so, we avoided the shortcomings of the existing literature in this area. The results of instrumental variable estimations show that our findings were unaltered. In fact, while macroeconomic factors are important determinant' of stock market capitalization, institutional environment has no effect on stock market development.

The remainder of the paper is structured as follows. Section 2 provides a brief literature review of macroeconomic and institutional driving forces for stock market development. Section 3 presents the evolution of the stock market in the MENA countries. Section 4 presents the data and the adopted econometric methodology. The empirical results are presented and interpreted in section 5 . Finally, section 6 offers some conclusions and policy recommendations.

\section{Determinants of Stock Market Development: A Brief Literature Review}

Major prior studies related to the present paper include Demirguç-Kunt and Levine (1996), Levine and Zervos (1998), Garcia and Liu (1999), Boyd, Levine and Smith (2001), Beck, Demirguc-Kunt and Levine (2003), Ben Naceur et al. (2007) as well as Yartey (2008). These studies focused on the effects of macroeconomic and institutional factors on stock market development in developed and developing countries. Unlike the study of Ben Naceur et al. (2007) conducted with a special focus on the MENA region, we added to the macroeconomic factors, the institutional determinants of the stock market development in this region.

In studies on finance and development, a causal relationship between financial development and economic growth has been suggested along three lines: firstly, financial deepening promotes economic growth; secondly, economic growth stimulates financial development; and thirdly, economic growth and financial development influence each other (Levine, 2005). Against this background, analyzing what determines stock market development has become a prominent topic in recent years. In this literature, macroeconomic and institutional factors have been found to be the most important driving forces for the development of stock markets.

A large body of evidence has documented the importance of macroeconomic conditions in determining financial development. Recent research shows that stock market development might boost economic growth, and empirical evidence tends to provide some support to this finding. Demirguc-Kunt and Levine (1996) examine the relationship between stock market development and financial intermediary in developing countries and find that most stock market

${ }^{1}$ Aghion, Alesina and Trebbi (2004) argue that political institutions influence economic policy, but they are themselves endogenous since they are chosen, in some way, by members of the polity. 
indicators are highly correlated with financial intermediary development. Levine and Zervos (1998) presented empirical evidence that stock market development plays an important role in predicting future economic growth.

Garcia and Liu (1999) investigated empirically the macroeconomic determinants of stock market development. Using pooled data from 15 industrial and developing countries from 1980 to 1995, they found that real income level and stock market liquidity are important predictors of market capitalization, while macroeconomic stability does not have any explaining power. They also concluded that banks and markets are complementary instead of being substitutes.

One of the basic pre-requisites for financial market development is macroeconomic stability. Using a cross sectional regressions and a dynamicpanel generalized-method of moments (GMM) estimator for a sample of 65

- countries over 1960-1995 period, Boyd et al. (2001) provided evidence that there is a significant and economically important negative relationship between inflation and financial development.

Building upon Garcia and Liu's (1999) work, Ben Naceur et al. (2007) examined the macroeconomic determinants of stock market development in the MENA region. Using an unbalanced panel data from 11 MENA countries (over 1979-1999) and employing fixed and random effects specifications, they found that saving rate, credit to private sector, the ratio of value traded to GDP and inflation change are the important determinants of stock market development. Similar to Garcia and Liu (1999), they also found that financial intermediaries and stock markets are complements rather than substitutes in the growth process.

There is also a substantial amount of research trying to identify the impact of the institutional quality on financial development. This strand of research goes back to the seminal contributions of La Porta, Lopez. de-Silanes, Sheifler and Vishny (1997 and 1998) on how the legal rules covering protection of corporate shareholders and creditors, the origin of these rules, and the quality of their enforcement affect financial development. Applying the propositions of La Porta et al. (1997 and 1998) to the transitions economies, Pistor,Raiser and Stanislaw (2000) found that the effectiveness of legal institutions has a stronger impact on equity and credit market development.

In an extension, Beck et al. (2003) evaluated empirically the law and endowments theories of financial development. Using cross-country regressions on a sample of 70 former colonies, they have provided evidence for both theories. Thus both legal systems and country's initial endowments are important determinants of financial development.

Using a new sample of 129 countries over 25 years, Djankov, McLiesh and Shleifer (2007) report that creditor protection through the legal system, and information sharing institutions are associated with higher ratios of private credit to GDP. Their results also showed that improvements in creditor rights or the introduction of credit registries ${ }^{2}$ leads to an increase in the private credit to GDP ratio. In addition, they reported that legal origins are an important determinant of both creditor rights and information sharing institutions.

\footnotetext{
${ }^{2}$ Information sharing institutions.
} 
Using Arellano and Bond Dynamic panel GMM estimations and several data sets over 1980-2003 periods, Baltagi, Demetriades and Law (2007) find that institutions can explain a large part of the variation in financial development across countries and over time. The predictions of the theoretical model developed by Holder (2007) are consistent with the previous empirical works. His finding shows that better property rights institutions make financial repression more costly for the elite and tend therefore to increase financial development. Their predictions also show that better contracting institutions lower the costs of financial transactions, which have countervailing effects on equilibrium financial development.

Girma and Shortland (2008) contributed to this literature by evaluating the influence of the political system and legal origin in financial development. Using panel data on developed and developing countries from 1975-2000, their results show that the degree of democracy and political stability are significant explanatory factors in determining the speed of financial development.

In a more recent study to examine the determinants of financial development, Law and Habibullah (2009) used data from 27 economies during 1980-2001. Their dynamic panel data analysis results demonstrated that institutional quality is a statistically significant determinant of banking sector development and capital market development.

Besides the legal framework discussed above, informal institutions begin to gain some attention among economists. Calderon et al. (2001) exploited the link between trust and both the structure and development of financial system. Examining the simple correlation analysis for a sample of 48 countries during 1980-1995, Calderon et al. (2001) find that trust is positively linked with both financial development and efficient financial structure. When they use the ordinary least squares regressions they have found that trust and rule of law are strongly related to financial system indicators.

In the empirical literature of stock market development, an oftencited paper related to our study is Yartey (2008). This study examines the macroeconomic and institutional determinants of stock market development. Using a panel data of 42 countries over 1990 to 2004, he found that income level, gross domestic investment, banking sector development, private capital flows, and stock market liquidity are important determinants of stock market development. He also provides evidence that institutional factors such as law and order, political risk, and bureaucracy quality are important determinants of stock market development.

\section{Stock Market Evolution in the MENA Region}

The MENA countries have reformed their financial sectors over the past three decades. However, while they have made progress, their efforts have been eclipsed by faster reform and growth in other parts of the world. The stock markets in our sample of MENA countries have seen considerable development since the 1990s. The market capitalization of MENA countries has risen from 
\$124 billion in 1995 to more than \$1635 billion in 2007 (World Development Indicators: WDI 2007).

To understand the economic importance of the stock market capitalization in our sample, we examined the capitalization ratio. This ratio is defined as the value of domestic equities traded on the market relative to GDP. As we can observe from Figure 1, this ratio has increased from 14\% in 1990 to about $104 \%$ in 2007 . The high growth of the capitalization ratio coincided also with an increase in the number of listed companies. The number of listed companies has more than doubled; growing from less than 1050 companies in 1990 to about 2400 companies in 2007.

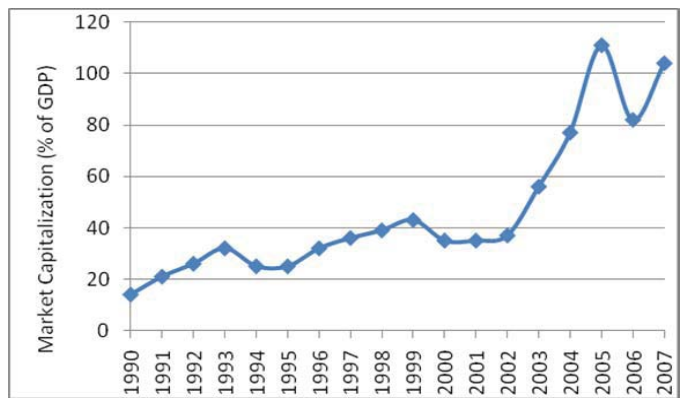

Figure 1. Stock Market Capitalization in the MENA countries (1990-2007)

Source: World Development Indicators (World Bank, 2007) and author's calculations.

To examine the MENA region stock markets depth, this paper measures the activity of stock market using the total value traded as share of GDP, which gives the value of stock transactions relative to the size of the economy. Figure 2 shows that this measure increased from about $4 \%$ in 1990 to roughly $56 \%$ in 2007.

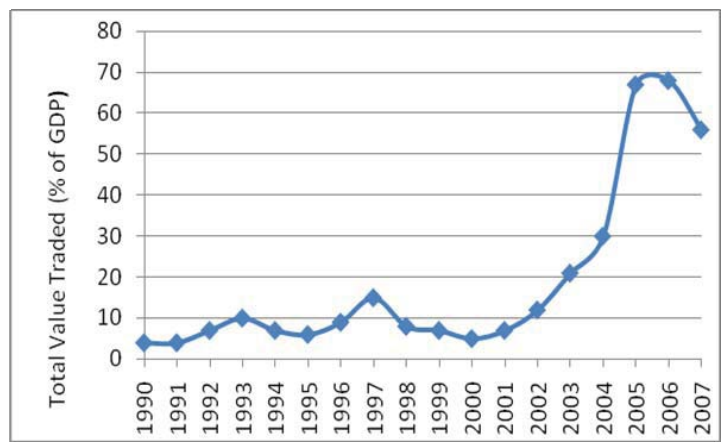

Figure 2. Total Value Traded per GDP in MENA countries (1990-2007)

Source: World Development Indicators (World Bank, 2007) and author's calculations. 
To clearly understand the liquidity picture, we examine the turnover ratio. The turnover ratio is defined as the ratio of the value of total shares traded to market capitalization. It measures the activity of the stock market transactions relative to its size. Many analysts use the turnover ratio as a measure of transactions costs. High turnover ratio implies high transaction and, consequently, high efficiency. In our sample of countries the turnover ratio has increased from under $33 \%$ in 1990 to about $49 \%$ in 2007 which can be interpreted as an efficiency gain in the MENA region stock markets.
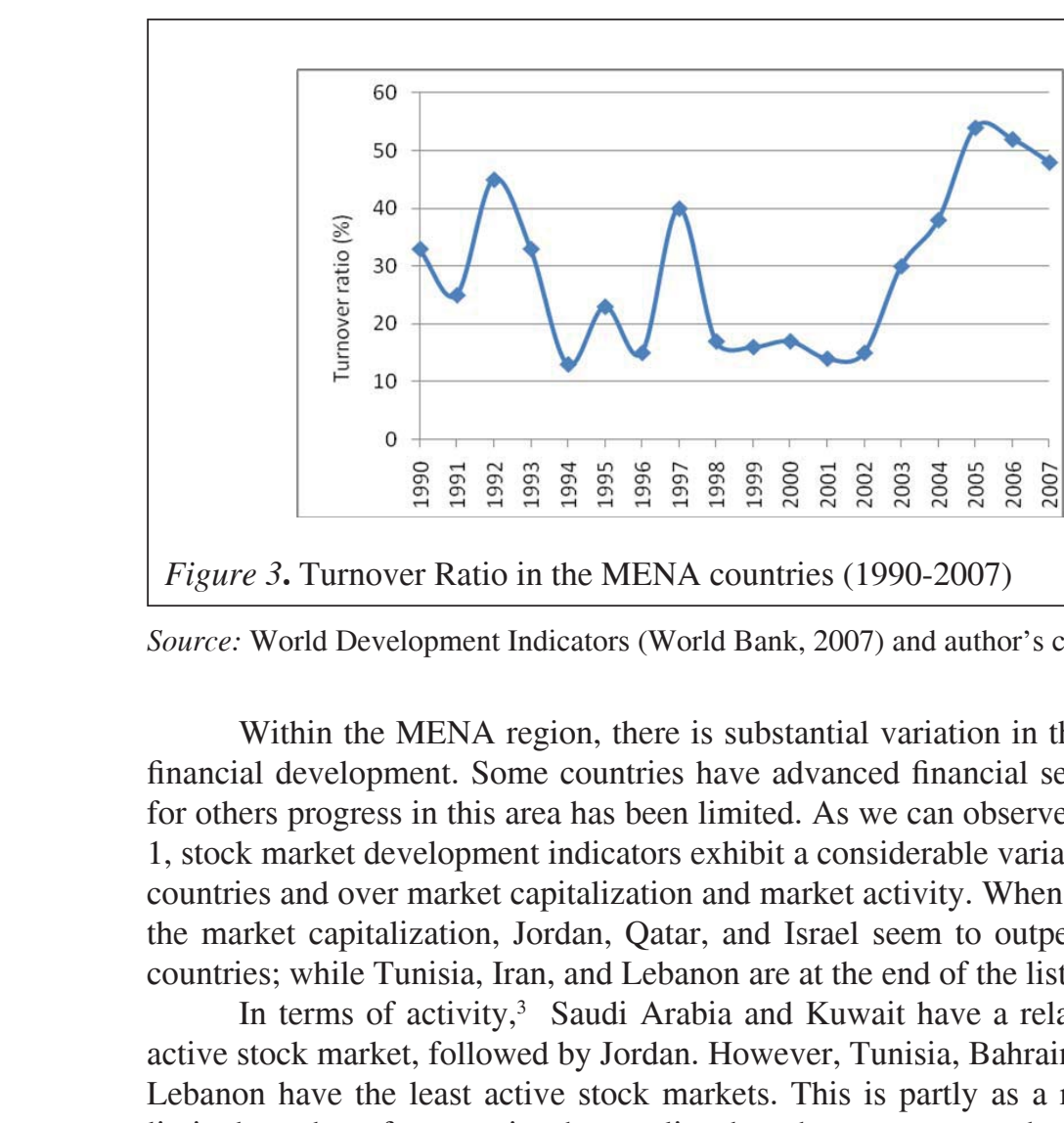

Figure 3. Turnover Ratio in the MENA countries (1990-2007)

Source: World Development Indicators (World Bank, 2007) and author's calculations.

Within the MENA region, there is substantial variation in the degree of financial development. Some countries have advanced financial sectors, while for others progress in this area has been limited. As we can observe from Table 1, stock market development indicators exhibit a considerable variability across countries and over market capitalization and market activity. When considering the market capitalization, Jordan, Qatar, and Israel seem to outperform other countries; while Tunisia, Iran, and Lebanon are at the end of the list.

In terms of activity, ${ }^{3}$ Saudi Arabia and Kuwait have a relatively more active stock market, followed by Jordan. However, Tunisia, Bahrain, Malta and Lebanon have the least active stock markets. This is partly as a result of the limited number of companies that are listed on these country exchanges.

For example, in 2007 the numbers of listed companies were 50, 15 and 11 in Tunisia, Malta and Lebanon respectively. Finally, on the basis of the turnover ratio, we find that Saudi Arabia has relatively the most liquid stock market followed by Kuwait.

${ }^{3}$ Following Demirguç-Kunt and Levine (1999), we consider the total value traded as a share of GDP as a measure of stock market activity. This measure is also used to gauge market liquidity because it measures trading relative to economic activity (Levine and Zervos, 1998). 
Table 1

Indicators of Stock Market Development in the MENA countries, 1990-2007

\begin{tabular}{lcccc}
\hline Country & $\begin{array}{c}\text { Number of listed } \\
\text { companies }\end{array}$ & $\begin{array}{c}\text { Market } \\
\text { Capitalization/ GDP }\end{array}$ & $\begin{array}{c}\text { Value Traded / } \\
\text { GDP }\end{array}$ & $\begin{array}{c}\text { Turnover } \\
\text { Ratio }\end{array}$ \\
\hline Bahrain & 43 & 0.992 & 0.0438 & 0.043 \\
Egypt & 435 & 0.339 & 0.096 & 0.292 \\
Iran & 329 & 0.143 & 0.022 & 0.162 \\
Israel & 654 & 0.583 & 0.292 & 0.466 \\
Jordan & 245 & 1.072 & 0.364 & 0.264 \\
Kuwait & 181 & 0.822 & 0.523 & 0.664 \\
Lebanon & 11 & 0.162 & 0.024 & 0.123 \\
Malta & 15 & 0.352 & 0.022 & 0.056 \\
Morocco & 74 & 0.312 & 0.056 & 0.175 \\
Oman & 125 & 0.239 & 0.060 & 0.250 \\
Qatar & 40 & 0.885 & 0.146 & 0.235 \\
Saudi Arabia & 111 & 0.616 & 0.745 & 1.012 \\
Tunisia & 50 & 0.118 & 0.013 & 0.100 \\
UAE & 90 & 0.468 & 0.194 & 0.483 \\
\hline
\end{tabular}

Source. World Development Indicators (World Bank 2007) and author's calculations.

\section{Data and Econometric Methodology}

The approach taken in this paper was to model the impact of macroeconomic and institutional factors on stock market development in MENA region. Our initial intention was to cover all countries in the MENA region, but given that some countries have not yet established stock markets (for example Djibouti, Libya, Syria, and Yemen) and other countries have established stock markets recently (for example, Algeria), the sample included are only 14 MENA countries: Bahrain, Egypt, Iran, Israel, Jordan, Kuwait, Lebanon, Malta, Morocco, Oman, Qatar, Saudi Arabia, Tunisia and UAE over the period of 1990-2007.

\section{A. The data}

Data were extracted from various sources. Employing the November 2008 Beck et al. (2000) database on financial development and structure, stock market and financial system indicators from 1990 to 2007 are extracted. Other information related to macroeconomic stability, saving and investment rates are collected from the World Development Indicators (World Bank, 2007) database. The institutional indicators were collected from the International Country Risk Guide (ICRG) compiled by the Political Risk Services (PRS Group). These indicators rely exclusively on polls of experts. The main advantages of these datasets are that they were available for a considerable time span; thus allowing to test the dynamics and relevance of institutions in affecting stock market development (Daude and Stein 2007). 
The dependent variable of interest is stock market development. Following Yartey (2008), we measured stock market development using market capitalization as a proportion of GDP. This measure equals the value of listed shares divided by GDP. ${ }^{4}$ The independent variables consisted of a set of macro and institutional factors as defined below.

\section{B. The variables}

\section{Macroeconomic factors}

As macroeconomic factors, we adopt those as defined in (Garcia and Liu (1999)). - Income level: Real income has been found to be highly correlated with the size of the stock market. We used the logarithm of the real GDP in US dollars to measure the income level. To avoid the causality problem, we simply use last year's income level. We expected to have a positive impact on stock market development.

- $\quad$ Savings: The saving rate is calculated as the ratio of gross saving to GDP. We expected a positive effect on the stock market size. To avoid the causality problem, we used last year's saving.

Investment rate: Investment is considered an important determinant of stock market capitalization as stock markets represent one way to intermediate saving to investment projects. We use the ratio of gross fixed capital to GDP as a measure of investment. We expect it to be the important determinant of stock market capitalization. To avoid the causality problem, we used last year's investment rate.

Financial intermediary development: Since both bank and stock markets channel savings toward investment projects, they can be either complements or substitutes. We used two indicators of financial intermediary development. The first was the domestic credit to private sector. This indicator measures the role of banks in providing long-term financing to private corporations. The second was the ratio of broad money supply M3 to GDP. This ratio is a measure of the size of the banking sector in relation to the economy as a whole.

Stock market liquidity: We used two indicators of stock market liquidity. The first is the turnover ratio, defined as the total value of domestic shares traded divided by market capitalization. It indicates the trading volume of the stock market relative to its size. The second is the value traded ratio, which equals the total value of domestic equities traded on each country's major stock exchanges as a percentage of GDP. We expected this measure to have a positive impact on stock market capitalization because a large amount of savings is channeled through stock markets.

${ }^{4}$ Stock market development is a multi-dimensional concept, it is usually measured by the number of listed companies, stock market liquidity, etc. We focused on market capitalization as a percentage of GDP because it is less arbitrary than the other measures. 
Macroeconomic stability: Macroeconomic stability may be an important factor for the development of the stock market. To determine the impact of macroeconomic stability on market capitalization, we used two indicators of macroeconomic stability: real interest rate and current inflation. We expected that there is a strong negative relationship between these two indicators and stock market development.

\section{Institutional Factors}

The study of the impact of the institutional environment on stock market development is related to the recent literature on the relationship between the legal institutional framework and corporate finance. We contribute to this

literature by looking at the link between stock market development and political risk, a measure of the institutional quality that supports the viability of external finance.

The paper looks also at the impact of institutional quality on stock market development because it is widely believed that the strengthening of institutions in a country could broaden appeal and confidence in stock market investment. As mentioned by Perotti and Van Oijen (2001), equity investment thus becomes gradually more attractive as political risk is resolved over time. Yartey (2008) showed that the political risk and institutions are strongly associated with growth in stock market capitalization. Thus, the development of good quality institutions (resolution of political risk) can be an important factor in the development of stock markets in emerging economies. Therefore, the development of good quality institutions can improve the attractiveness of equity investment and lead to stock market development.

To assess the role of public institutions in determining stock market development, we constructed a yearly composite political risk index ${ }^{5}$ using the ICRG variables from the PRS Group. The composite index is the sum of the 12 indices of government stability, socioeconomic conditions, investment profile, internal conflict, external conflict, corruption, military in politics, religion in politics, law and order, ethnic tensions, democratic accountability, and bureaucracy quality. This index ranges from zero to one hundred, with lower values suggesting poorly performing institutions. We expected countries with good quality of institutions and therefore low political risk to have welldeveloped stock markets.

\footnotetext{
${ }^{5}$ To capture the effect of institutional quality on the flows of capital from rich countries to poor countries, Alfaro, Kalemli-Ozkan and Volosovych (2008) constructed a yearly composite index using the ICRG variables from the PRS group (2001). To examine the institutional determinants of financial flows, Papaionnou (2009) also used a proxy of institutional quality, a composite indicator constructed by PRS, namely, the ICRG "political risk" rating.
} 
In accordance with Yartey (2008), who argued that the political risk indicator has a problem in the sense that it imparts very little direction toward targeting a particular aspect of institutions, we considered the impact of four sub-indicators of the composite ICRG index on stock market development: law and order, bureaucracy quality, democratic accountability, and corruption. ${ }^{6}$

Quality of bureaucracy: [0-6] high points are given to countries where the bureaucracy has the strength and expertise to govern without drastic changes in policy or interruptions in government services.

- Law and Order: [0-6] index where higher scores indicate sound political institutions, a strong court system, and provision for an orderly succession of power.

Corruption: [0-6] index refers to corruption in the political system. Countries that have low levels of corruption have high values of the index and vice versa.

Democratic accountability: [0-4] this is a measure of how responsive the government is to its people.

\section{Econometric Methodology}

The model to be estimated is the following:

$$
\begin{aligned}
& \text { Yi,t }=\alpha i+\beta \text { MACROi,t } t+\theta \text { INSTit }+\mu i, t, \text { for } i=1,2, \ldots N, t=1,2, \ldots \text { Ti } \\
& \text { for } i=1,2, \ldots N, t=1,2, \ldots \text { Ti }
\end{aligned}
$$

where $\mathrm{Y}_{\mathrm{i}, \mathrm{t}}$ the dependant variable, is defined as MCAP, MACRO is a matrix of macroeconomic variables made up of income level, saving rate, investment rate, credit to private sector, M3 to GDP, stock market liquidity, and macroeconomic instability. The INST variable is the indicator of institutional quality, $\alpha \mathrm{i}$ is the unobserved country specific fixed effect, and $\mu_{\mathrm{i}, \mathrm{t}}$ is the error term for each observation.

Fixed effects as well as random effects models were considered in this study. We used the Hausman test to select the appropriate estimator. If the Hausman test rejects the null hypothesis that the individual effects are not correlated with the explanatory variables, the most suitable estimation would then be the fixed-effects model. ${ }^{7}$

While the panel data techniques (fixed effects and random effects specifications) account for time-invariant country characteristics and time trends that may influence stock market development, fixed and random effects models are not a panacea, since reverse causation and measurement error might still plague the estimates when we consider the institutional quality. Thus, when

\footnotetext{
${ }^{6}$ The four measures were chosen because of their importance in past results. Yartey (2008) found that law and order, democratic accountability, and bureaucracy quality are important for stock market development.

${ }^{7}$ Fixed effects model indicates that the individual effects are correlated with the explanatory variables.
} 
we considered the institutional quality, we used the instrumental variable (IV) techniques in addition to the fixed effects and random effects models. Besides endogeneity, the instrumental variable (IV) estimates also accounted for measurement error in the institutional proxies.

\section{The Results}

The results were grouped and presented in three sub-sections: (a) macroeconomic determinants of stock market development, (b) institutional quality and stock market development, and (c) unbundling. As a prelude to these three categories, Table 2 provides summary statistics on the variables.

Table 2

Descriptive Statistics

\begin{tabular}{lrccc}
\hline Variable & Mean & Std. Dev. & Min & Max \\
\hline Market Capitalization & .481 & .479 & .019 & 2.98 \\
Income level & 10.407 & .522 & 9.283 & 11.552 \\
Saving Rate & .212 & .107 & -.044 & .419 \\
Investment Rate & .221 & .054 & .106 & .392 \\
Value Traded & .181 & .465 & .0007 & 3.934 \\
Turnover Ratio & .288 & .399 & .008 & 2.884 \\
Domestic credit & .570 & .213 & .206 & 1.157 \\
M3/GDP & .801 & .416 & .260 & 2.490 \\
Inflation & .060 & .096 & -.013 & .807 \\
Interest rate & .060 & .084 & -.362 & .314 \\
Political Risk Index & 67.183 & 10.021 & 10.333 & 87.583 \\
\hline
\end{tabular}

\section{A. Macroeconomic Determinants of Stock Market Development}

Table 3 summarizes the results of the fixed and random effects models for the sample of the 14 MENA countries from 1990 to 2007. In the first column of Table 2, we present results when we include only the last year's income, last year's saving rate, domestic credit to the private sector divided by GDP and last year's value traded to GDP ratio in the regression (1). We used it as the basic regression. The results showed that last year's saving rate, domestic credit to private sector and last year's traded to GDP ratio have a positive and significant effect on stock market capitalization. Conversely, last year's income has no significant impact on market capitalization. When last year's saving increases by 
one percentage point, market capitalization increases by 1.58 percentage points, which implies that most of the increase in savings is channeled through the stock markets. If value traded to GDP ratio increases by one percentage point, market capitalization increases by 1.06 percentage points. Therefore, stock market liquidity has a positive effect on market capitalization. Financial intermediaries also promote stock market development. When domestic credit to private sector increases by one percentage point, stock market capitalization increases by 1.22 percentage points.

To test the effect of the investment rate on stock market capitalization, regression (2) includes last year's investment instead of savings rate. The result showed that investment rate is not a good predictor of market capitalization, since its coefficient is insignificant. However, contrary to regression (1), income level has a significant and a positive effect on stock market capitalization.

To test the effect of an alternative measure of financial intermediary development on market capitalization, regression (3) includes M3 to GDP ratio instead of domestic credit to private sector. This confirmed the positive impact of financial intermediary growth on development of the stock market. Comparing regressions (1) and (3), we recorded that domestic credit to the private sector seems to be a better measure of financial intermediary and a better predictor of stock market development. If M3 to GDP ratio increases by one percentage point, market capitalization increases by 0.48 percentage points. This is consistent with our expectation.

In order to test the incidence of another measure of stock market liquidity, regression (4) includes least year's turnover ratio instead of the ratio of value traded to GDP. The turnover ratio has a positive and significant effect on market capitalization. When last year's turnover ratio increases by one percentage point, market capitalization increases by 0.87 percentage points. Comparing regressions (1) and (4), we can see that the value traded to GDP is a better measure of stock market liquidity, and plays a more important role in determining stock market capitalization.

To investigate the effect of macroeconomic stability, current inflation is introduced in model (5). Inflation has a positive sign even though it is not statistically significant. To examine the effect of real interest rate on stock market capitalization, we used real interest rate instead of inflation in model (6). The results show that last's year income, saving rate, and value traded are all positive and statistically significant in explaining stock market capitalization. Real interest rate is significant and has the expected negative sign. Finally to test the hypothesis that the investment rate is a better predictor of stock market capitalization than the savings rate, we compared regressions from (3)-(6) with regressions (7)-(10) when we employ the investment rate instead of savings rate. The results proved the predominance of savings rate as a best predictor of stock market capitalization. 


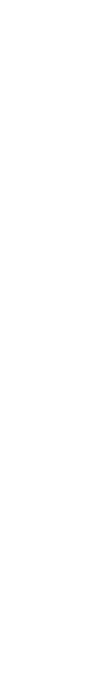

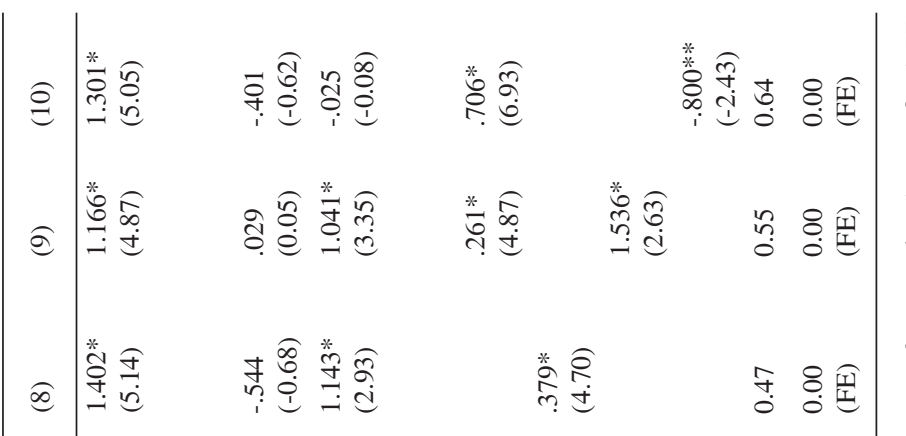

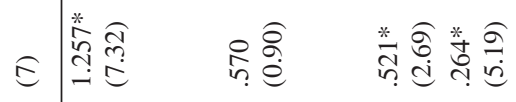

ำ 웅

Q

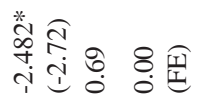

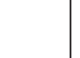

$\approx$

* 6 * *

* * (n)

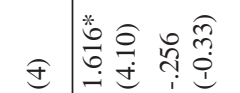

๙ุ่

赵

ลิ

ڤి. 8 :

约

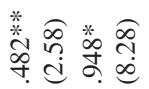

華命

$\circ$ 요

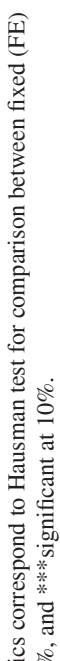

趈

氙

वิ

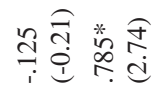

*.

กุ: 웜

तิ

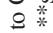

을

言

密

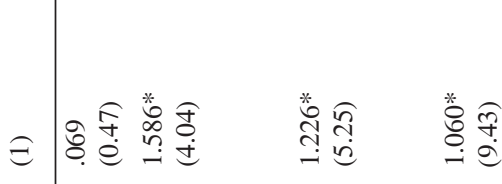

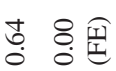

؛ิ

$F$ 


\section{B. Institutional Quality and Stock Market Development}

We now report the impact of institutions on stock market development. The results of the panel and instrumental variable estimations are presented in Table 4. To test the effect of institutional quality on stock market development, we added the political risk index to our baseline regression. ${ }^{8}$ As we can see, last's year income level, savings rate, and total value traded have a positive and significant effect on stock market capitalization. The domestic credit to private sector was also positive but statistically insignificant.

The political risk index has the expected positive sign even though it is not statistically significant. This outcome indicates that institutional environment is not a good predictor of stock market development in MENA countries. Our second approach was to run IV regressions using instruments that are not subject to reverse causality and can account for the institutional variation. Following the institutions and development theories (Mauro 1995 ${ }^{9}$; Daude and Stein 2007) ${ }^{10}$, we use the indicators of ethnic diversity as instruments.

La Porta, Loped-de-Silanes, Sheifler and Vishny (1999) pointed out that ethnic diversity leads to corruption and low efficiency in governments that expropriate the ethnic losers. Several authors have interpreted the finding of a positive relationship between ethnic diversity and poor economic performance to be a consequence of the high probability of conflict associated with a highly fractionalized society ${ }^{11}$. For this reason, many papers use the ethno-linguistic fractionalization index as the indicator of ethnic heterogeneity. In a more recent study, Aghion et al. (2004) argued that racial fragmentation and institutions are not independent from each other. Building on this theory, we use in regression (2) an index of ethnolinguistic fragmentation from Roeder (2001) as an instrument of political risk index. The first interesting result is that in term of significance, the results are analogous to the fixed effect models. Thus, political risk index has a negative sign even though it is not a significant determinant of stock market development.

In contrast, Fearon (2003) pointed out that the index of fractionalization ${ }^{12}$ cannot capture important differences in ethnic structures. Similarly, Montalvo, and Reynal-Querol (2005) argued that the measure of ethnic heterogeneity

\footnotetext{
${ }^{8}$ Regression (1) Table (2).

${ }^{9}$ To instrument corruption Mauro (1995) has used the ethno-linguistic fragmentation.

${ }^{10}$ To instrument political stability and freedom Daude and Stein (2007) have used also the ethno-linguistic fragmentation.

${ }^{11}$ Easterly and Levine (1997) found empirical evidence to support their claim that the very high level of ethnic diversity of countries in Africa is an important contributor to their poor economic performance.

${ }^{12}$ The index of ethnic fractionalization is the probability that two randomly selected individuals from a given country will not belong to the same ethnic group.
} 

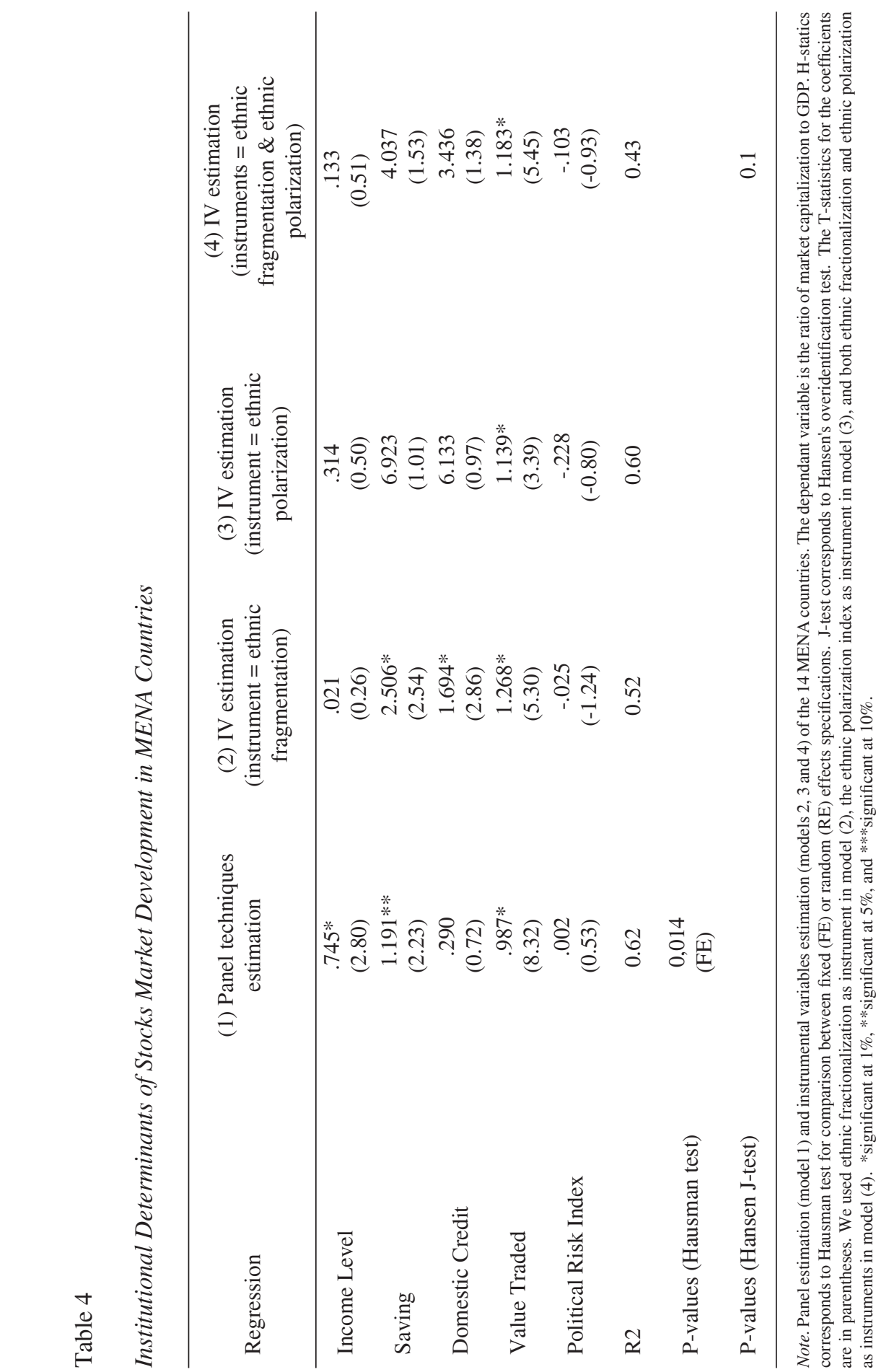
appropriate to capture potential conflict should be a polarization measure ${ }^{13}$. In fact, in accordance with Horowitz (1985), Montalvo, and Reynal-Querol (2005) showed that the most severe conflicts arise in societies where a large ethnic minority faces ethnic majority. The index of ethnic fractionalization is not able to capture this idea appropriately. As the result, in regression (3) we used the ethnic polarization ${ }^{14}$ from Montalvo and Reymal-Querol (2005) as an instrument of institutional quality. As with ethnolinguistic fractionalization, this instrumentation strategy also suggests that the index of political risk has no significant effect on stock market capitalization. Thus, the political risk index appears an insignificant determinant of stock market development.

Regression (4) reports IV models using the two indicators of ethnic diversity (ethnic fragmentation and ethnic polarization) as instruments for institutional development. This approach is the most efficient since it helps obtain a stronger first stage fit and more properly isolate the exogenous components of institutions. It is also helpful, since having more than one instrument, one can test for instrument validity performing. We used Hansen's over identification test (J-test) to check the null hypothesis of whether the instruments for institutions we chose are valid. P-values for the over identification $(10 \%)^{15}$ suggest that we cannot reject the null hypothesis of instrument validity.

\section{Unbundling}

As mentioned earlier, the problem with the concept of political risk index is that it tells us very little about which aspect of institution policies should be targeted for change. To remedy this deficiency, the paper studied the impact of some components within the index of political risk on stock market development. The results are reported in Table 5.

In regression (1), we used the protection against corruption index. The coefficient on corruption is statistically insignificant at standard confidence levels.

In regression (2), we looked at the effect of bureaucratic quality. Good bureaucracy quality enhances the regulatory capacity of countries and therefore should be positively associated with stock market development. However, the result shows that bureaucracy quality does not appear a significant determinant of stock market development. Democratic accountability and law and order do not also appear a significant determinant of market capitalization in MENA countries.

\footnotetext{
${ }^{13}$ In the fractionalization index, the size of each group has no effect on the weight of the probabilities of two individuals belonging to different groups, whereas in the polarization index these probabilities are weighted by the relative size of each group. See Montalvo and Reynol (2005) for more explications.

${ }^{14}$ Papaioannou. (2009) has used ethnic polarization to instrument institutional quality.

${ }^{15}$ The P-values (10\%) exceed the conventional 5\% significance level.
} 
Table 5

Institutional Determinants (Sub-Indicators of political risk index) of Stock Market Development in MENA Countries

\begin{tabular}{|c|c|c|c|c|}
\hline Regression & $(1)$ & $(2)$ & (3) & $(4)$ \\
\hline Income Level & $\begin{aligned} .008 \\
(0.01)\end{aligned}$ & $\begin{array}{l}.779 * \\
(3.13)\end{array}$ & $\begin{array}{r}.069 \\
(0.64)\end{array}$ & $\begin{array}{r}.029 \\
(0.38)\end{array}$ \\
\hline Saving & $\begin{array}{l}1.714 * \\
(4.72)\end{array}$ & $\begin{array}{l}1.269 * * \\
(2.35)\end{array}$ & $\begin{array}{l}1.556^{*} \\
(3.83)\end{array}$ & $\begin{array}{l}1.672^{*} \\
(4.93)\end{array}$ \\
\hline Domestic Credit & $\begin{array}{l}1.190^{*} \\
(5.05)\end{array}$ & $\begin{array}{r}.294 \\
(0.73)\end{array}$ & $\begin{array}{l}1.187 * \\
(4.81)\end{array}$ & $\begin{array}{l}1.222^{*} \\
(5.49)\end{array}$ \\
\hline Value Traded & $\begin{array}{l}1.129 * \\
(9.66)\end{array}$ & $\begin{array}{l}.983 * \\
(8.27)\end{array}$ & $\begin{array}{l}1.056^{*} \\
(9.29)\end{array}$ & $\begin{array}{l}1.120^{*} \\
(9.84)\end{array}$ \\
\hline Bureaucratic Quality & & $\begin{array}{r}-.076 \\
(-0.72)\end{array}$ & & \\
\hline Corruption & $\begin{array}{r}-.019 \\
(-0.61)\end{array}$ & & & \\
\hline Accountability & & & $\begin{array}{r}.011 \\
(0.42)\end{array}$ & \\
\hline Law and Order & & & & $\begin{array}{r}.017 \\
(0.94)\end{array}$ \\
\hline $\mathrm{R} 2$ & 0.59 & 0.62 & 0.60 & 0.58 \\
\hline $\begin{array}{l}\text { H- statistic } \\
\text { (Hausman specification) }\end{array}$ & $\begin{array}{l}0.19 \\
(\mathrm{RE})\end{array}$ & $\begin{array}{l}0.04 \\
(\mathrm{FE})\end{array}$ & $\begin{array}{l}0.24 \\
(\mathrm{RE})\end{array}$ & $\begin{array}{l}0.14 \\
(\mathrm{RE})\end{array}$ \\
\hline
\end{tabular}

Note: Panel estimations of the 14 MENA countries. The dependant variable is the ratio of

market capitalization to GDP. H-statistics corresponds to Hausman test for comparison between fixed (FE) or random (RE) effects specifications. The T-statistics for the coefficients are in parentheses. *significant at $1 \%, * *$ significant at $5 \%$, and $* * *$ significant at $10 \%$.

\section{Conclusions and Policy Recommendations}

Stock market development is an integral part of financial development, which is, in turn, associated with economic growth. In this paper, we have highlighted the role of selected macroeconomic and institutional variables in explaining stock market development in 14 MENA countries for the period 1990-2007. According to previous studies, institutional factors as political risk, law and order, democratic accountability and bureaucratic quality are important determinants of stock market development in emerging markets. Hence, the resolution of political risk can increase investor confidence and propel the growth of the stock markets in emerging economies.

The empirical analysis found three interesting results. Firstly, we have found that while savings rate, financial intermediary, stock market liquidity, interest rate and income are important determinants of stock market development, investment and inflation do not prove to be significant. Secondly, the banking sector is a complement to the stock market in financing investment and in the 
growth process in MENA region. These first results are generally in agreement with the theoretical and empirical literature.

Lastly, when we considered the institutional environment, and in contrast to some recent research (Yartey, 2008), we found that the index of political risk has no significant effect on stock market capitalization. Our results are robust to the use of different econometrics strategies. In fact, when we instrumented the political risk index by both ethnic fragmentation and ethnic polarization, the results were similar to those of panel data estimates.

Our findings have important policy implications for MENA countries. Firstly, economic growth plays a crucial role in stock market development. Policymakers in MENA may initiate policies to foster growth and development as countries liberalize their financial system. Secondly, a well-developed banking sector is important for stock market development in the region and can play a driving force in promoting the stock market as demonstrated by the experiences of many East Asian countries. Thirdly, domestic savings is an important determinant of stock market development in the MENA countries. Thus, MENA policymakers should encourage savings by appropriate policies. Fourthly, stock market liquidity has a positive impact on stock market development. Consequently, improving stock market liquidity can be another tool for promoting stock market development. Finally, even if our empirical results do not show a positive effect on institutional quality on stock market development, MENA countries should improve their institutional framework because good institutions reduce political risk which is an important factor in investment decision.

Author statement: Mondher Cherif would like to acknowledge Chaire AG2R Prémalliance "Finance Autrement: Investissement - Solidarités - Responsabilité" for the support of this research. He is a professor at the Rheims University: he also holds another position as shown earlier. Email: mondherc@gmail.com.

\section{References}

Aghion, P., Alesina, A., and Trebbi, F. (2004). Endogenous political institutions. Quarterly Journal of Economics, 119 (2), 565-613.

Alfaro, L., Kalemli-Ozkan, S., and Volosovych, V. (2008). Why dosen't capital flow from rich to poor countries? An empirical Iinvestigation. Review of Economics and Statistic , 90 (2), 347-368.

Baltagi, B. H., Demetriades, P. , and Law, S.H. (2007). Financial development, openness and institutions: Evidence from panel data. Center for Policy Research Working Papers No.7.

Beck, T., Demirguç-Kunt, A., and Levine, R. (2000). A new database on financial development and structure. World Bank Economic Review, 14 (3), 597-605. 
Beck, T., Levine, R. , and Loayza, N. (2000). Finance and the sources of growth. Journal of Financial Economics, 58 (1-2), 261-300.

Beck, T., and Levine, R. (2004). Stock markets, banks and growth: Panel evidence. Journal of Banking and Finance, 28 (3), 423-442.

Beck, T., Demirguc-Kunt, A., and Levine, R. (2003). Law, endowments, and finance. Journal of Financial Economic , 70 (2), 137-181.

Ben Naceur, S., Ghazouani, S., and Omrani, M. (2007). The determinants of stock market development in the MENA region. Managerial Finance, 33 (7), 477-489.

Boyd, J.H., Levine, R., and Smith, B.D. (2001). The impact of inflation on financial sector performance. Journal of Monetary Economics, 47 (2), 221-248.

Daude, C. and Stein. E. (2007). The quality of institutions and foreign direct investment. Economics \& Politic, 19 (3), 317-344.

Demirguç-Kunt, A., and Levine, R. (1996). Stock markets, corporate finance, and economic growth: An overview. World Bank Economic Review, 10 (2), 223-239.

Djankov, S., McLiesh, C., and Shleifer, A. (2007). Private credit in 129 countries. Journal of Financial Economics, 84 (2), 299-329.

Easterly, W., and R. Levine. (1997). Africa's growth tragedy: Policies and ethnic divisions. Quarterly Journal of Economic , 112 (4), 1203-1250.

Fearon, J.D. (2003). Ethnic and cultural diversity by country. Journal of Economic Growth, 8 (2), 195-222.

Holder, R. (2007). Institutions, trade and the political economy of financial development. NNCR Ttrade Regulation, Swiss National Centre of Competence in Research, Working paper No. 2007/27.

Horowitz, D.L. (1985). Ethnic Group in Conflict. Berkeley: University of California Press.

Garcia , V.F., and Liu, L. (1999). Macroeconomic determinants of stock market development. Journal of Applied Economics, II (1), 29-59.

Girma, S. and Shortland, A. (2008). The political economy of financial development. Oxford Economic Papers, 60 (4), 567-596.

King, R.G., and Levine, R. (1993a). Finance and growth: Schumpeter might be right. Journal of Economics, 10 (3), 717-738.

King, R.G., and Levine, R. (1993b). Finance, entrepreneurship, and growth: Theory and evidence. Journal of Monetary Economics, 32 (3), 513-542.

La Porta, R., Lopez-de-Silanes, F., Sheifler, A., and Vishny, R.W. (1999). The quality of government. Journal of Law, Economics and Organization, 15 (1), 222-279.

La Porta, R., Lopez-de-Silanes, F., Sheifler, A., and Vishny , R.W. (1998). Law and finance. Journal of Political Economy, 106 (6), 1131-1150.

La Porta, R., Lopez-de-Silanes, F., Sheifler, A., and Vishny, R.W. (1997). Legal determinants of external finance. Journal of Finance, 53 (1), 1131-1155.

Levine, R. (1997). Financial development and economic growth: Views and agenda. Journal of Economic Literature, 35 (2), 688-726. 
Levine, R., Loayza, N. and Beck, T. (2000). Financial intermediation and economic growth: Causality and causes. Journal of Monetary Economics, 46 (1), 31-77.

Levine, R. and Zervos, S. (1998). Stock markets, banks, and economic growth. American Economic Review, 88 (3), 537-558.

Levine, R. (2005). Finance and growth: Theory and evidence. In P. Aghion and S. Durlauf (Eds.), Handbook of economic growth. Elsevier: Amsterdam.

Law, S.H., and Habibullah, M.S. (2009). The determinants of financial development: Institutions, openness and financial liberalization. South African Journal of Economics, 77 (1), 45-58.

Mauro, P. (1995). Corruption and growth. Quarterly Journal of Economics, 110 (3), 681-712.

Montalvo, J.G., and Reynal-Querol, M.(2005). Ethnic polarization, potential conflict and civil wars. American Economic Review, 95 (3), 796-816.

Papaioannou, E. (2009). What drives international financial flows? Politics, institutions and other determinants. Journal of Development Economics, $88(2), 269-281$

Pagano, M. (1993). Financial markets and growth: An overview. European Economic Review , 37 (2-3), 613-622.

Perotti, C. E., and Van Oijen, P. (2001). Privatisation, political risk and stock market development in emerging economies. Journal of International Money and Finance, 20 (1), 43-69.

Pistor, K., Raiser, M., and Stanislaw, G. (2000). Law and finance in transition economies. Economics of Transitio, 8 (2), 325-368.

Roeder, P.G. (2001). Ethnolinguistic Fractionalization (ELF) Indices, 1961 and 1985. Retrieved from http//:weber.ucsd.edul proederlelf.htm

Yartey, C. A. (2008). The determinants of stock market development in emerging economies: Is South Africa different? IMF Working Paper No.08/32.

Zoli, E. (2007). Financial development in emerging Europe: The unfinished agenda. IMF Working Paper No. 07/245. 


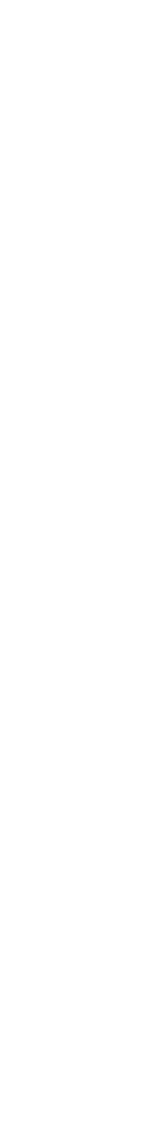

